\title{
BREADMAKING POTENTIAL AND PROTEOLYTIC ACTIVITY OF WHEAT VARIETIES FROM TWO PRODUCTION YEARS WITH DIFFERENT CLIMATE CONDITIONS
}

\author{
Jelena M. Tomić ${ }^{1 *}$, Aleksandra M. Torbica ${ }^{1}$, Ljiljana M. Popović ${ }^{2}$, Slađana M. Rakita ${ }^{1}$, \\ Dragan R. Živančev ${ }^{1}$ \\ ${ }^{1}$ University of Novi Sad, Institute of Food Technology, \\ Bulevar cara Lazara 1, 21000 Novi Sad, Serbia \\ ${ }^{2}$ University of Novi Sad, Faculty of Technology, Bulevar cara Lazara 1, \\ 21000 Novi Sad, Serbia
}

\author{
${ }^{*}$ Corresponding author: \\ Phone: +381214853780 \\ Fax: +38121450725 \\ E-mail address: jelena.tomic@fins.uns.ac.rs
}

\begin{abstract}
The wheat flour represents a complex system whose quality is influenced by several factors such as genotype, growing conditions and the complex interaction of genetic and environmental factors. In recent years, wheat quality fluctuation has become a major issue for millers and bakers. Requirements of bakery industry for providing wheat flour of uniform quality impose the need for further investigation in direction of monitoring/improving wheat flour quality. Therefore, the objective of the present study was to evaluate wheat varieties, grown in different locations, by breadmaking potential and proteolytic activity in dependence of climate conditions. Wheat flour of four wheat varieties (Pobeda, Zvezdana, Gordana and Apache), from seven locations in Serbia characterized by different climatic conditions in two production years, were used in this study. The analyses included a determination of proteolytic activity and the rheological properties of dough. Rheological properties of wheat flour dough were determined by Gluten index and Brabender equipment (Farinograph, Extensograph and Amylograph). The studies ended with a trial baking and estimation of textural properties of obtained bread. Large variability for all attributes evaluated was observed, with wider ranges in quality parameters across varieties than among growing locations. Wheat flour samples from 2012 production year were characterized by inferior quality parameters. Proteolytic activity and bread specific volume values for 2012 production year were significantly lower compared to 2011. These results indicate that level of proteolytic activity was under optimum for obtaining bread with higher specific volume.
\end{abstract}

Key words: wheat flour, breadmaking properties, proteolytic activity

\section{INTRODUCTION}

The modern baking industry requires a high level of uniformity in wheat flour quality that satisfies the requirements of automatic processing. The achievement of these demands is very difficult because the wheat quality is influenced by several factors such as genotype, growing conditions and the complex interaction of genetic and environmental factors (Vázquez et al., 2012). Bearing in mind the demand of bakery industry, understanding these effects is of great importance primarily for the development of wheat varieties with specific and consistent quality traits. Many studies have been conducted in an attempt to explain variations in the quality of wheat as a function of genetic variability, growing conditions and their interactions (Preston et al., 2001; Zhang et al., 2004). The influence of mentioned factors is manifested through changes in wheat grain, primarily on starch (a key factor for yield) 
and protein (a critical factor for the quality) component (Altenbach, 2012).

Relations between environmental conditions, yield and quality of wheat are very complex as evidenced by the numerous scientific researches (Zhang et al., 2004; Souza et al., 2004; Finlay et al., 2007). There are certain number of contradictory studies about which factor (genotype or environment) is more important for most quality characteristics. Many studies indicate that the magnitude of the effect of genotype and environment differs among quality parameters (Denčić et al., 2011; Wrigley, 2007).

There are different methodological approaches for defining the characteristics of wheat flours. Commonly used methods for assessing the wheat quality are empirical rheological methods such as Farinograph, Mixograph, Extensograph, Alveograph and Amylograph. During the last few years, the relatively new rheological device Mixolab has been largely used for fast wheat quality assessment (Dapčević et al., 2009). Although the wheat quality assessment is based on information obtained through the sensory, chemical, rheological and technological analyses, the baking test remains a key method to evaluate flour quality (Gélinas and McKinnon, 2011).

Regarding the proteolytic activity, their impact on the quality of wheat flour dough due to changes in the protein gluten has been the subject of considerable research and controversy (Kruger et al., 1977; Dominguez and Cejudo, 1996; Calucci et al., 2004). There is a general belief that the proteolytic activity in sound wheat is very low and, as such, has little signifycance in the change of wheat flour breadmaking potential (Rani et al., 2001). On the other hand, increased proteolytic activity in the germinated wheat leads to a reduction in the gluten quantity and its poorer rheological properties, as shown by a decrease in the water holding capacity of flour, shorter dough development and stability period and an increased softening (Dojczew and Sobczyk, 2007).

In recent years, as a consequence of altered climate conditions, quality fluctuation has become a major issue which is reflected through the changes in protein, carbohydrate and enzyme complex of wheat grain. Consequently, a new climate trends impose the need for further investigation in direction of monitoring/improving wheat flour quality.

The objective of the present study was to evaluate wheat varieties, grown in different locations, by breadmaking potential and proteolytic activity in dependence of climate conditions.

\section{MATERIAL AND METHODS}

\section{Material}

Four wheat varieties of Triticum aestivum Pobeda (Pob), Zvezdana (Zve), Gordana (Gord) and Apache (Ap) grown in two production years (2011 and 2012) at seven locations in Northern Serbia were selected for the study. Pobeda, Zvezdana and Gordana were bred by the Institute of Field and Vegetable Crops, Novi Sad, Serbia, whereas Apache was bred by Limagrain, Chappes, France. The samples were cleaned and tempered according to the AACC 26-10.02 and milled to laboratory flour using a Bühler MLU 202 mill (Bühler, Uzwil, Switzerland) according to the AACC 26-31.01 (AACC, 1999).

Meteorological data for period from May to July (from anthesis to harvest maturity) were collected by automatic hydrological stations (provided by the Agricultural Advisory Services). The 2011 production year was characterized by lower temperatures, drier conditions with an average growing season temperature across the locations from $16.6^{\circ} \mathrm{C}$ (for May) to $23.2^{\circ} \mathrm{C}$ (for July). Maximum daily temperatures, for the May and July, were above $31{ }^{\circ} \mathrm{C}$ and $38{ }^{\circ} \mathrm{C}$, respectively. The number of days with maximum temperatures above $30{ }^{\circ} \mathrm{C}$ for the tested locations ranged from 12 to 26. The 2012 production year was much warmer, with an average growing season temperature range across the locations of 25 (for May) to $32{ }^{\circ} \mathrm{C}$ (for July). June and July were characterized by deficient precipitation with extremely high maximum temperatures. Maximum temperatures were above $35^{\circ} \mathrm{C}$. The number of days with maximum temperatures above 
$30{ }^{\circ} \mathrm{C}$ was markedly higher than in the 2011 production year (from 31 to 41).

\section{Rheological properties of the flour sam- ples}

The rheological properties of wheat dough were determined using the Brabender Farinograph according to ICC 115/1, the Brabender Extensograph according to ICC 114/1, the Brabender Amylograph according to ICC 126/1, the Chopin Alveograph according to ICC 121 (ICC, 1992).

\section{Gluten index (GI)}

Gl was measured in two different ways: according to the ICC standard method 155 (ICC, 1994) and after incubation of a dough ball at $37^{\circ} \mathrm{C}$ for $90 \mathrm{~min}\left(\mathrm{Gl}\left(37^{\circ} \mathrm{C}\right)\right)$ (Torbica et al., 2007).

\section{Measurement of proteolytic activity}

Proteolytic activity of wheat flour was determined as described by Calucci et al. (2004) and Strelec et al. (2007) with some modifications. Flour $(2.5 \mathrm{~g})$ was suspended in $5 \mathrm{ml}$ sodium acetate buffer (50 $\mathrm{mM}, \mathrm{pH}$ 5.0). The proteolytic activity was measured by using $1 \%(\mathrm{w} / \mathrm{v})$ hemoglobin $(\mathrm{Hb})$ as a substrate. The reaction was initiated by adding flour extract $(600 \mu \mathrm{L})$ in $2.7 \mathrm{~mL}$ of $\mathrm{Hb}$ and after incubation at $45^{\circ} \mathrm{C}$ for $1 \mathrm{~h}$ terminated by adding $25 \%(\mathrm{w} / \mathrm{v})$ trichloroacetic acid (TCA). After the centrifugation (10 min at $15000 \mathrm{~g}$ ), $0.5 \mathrm{~mL}$ of the supernatant was utilized to determine the TCA-soluble products by the Lowry method (Lowry et al., 1951). At least three replicates were performed for each analysis.

\section{Breadmaking procedure}

Baking trials were conducted under laboratory conditions. For $300 \mathrm{~g}$ tin bread making method, the test baking formula was: $300 \mathrm{~g}$ of flour $(14 \mathrm{~g} / 100 \mathrm{~g}$ moisture basis), $2 \%$ fresh compressed yeast (flour basis) and $2 \%$ salt (flour basis). The total volume of water required for dough consistency of $400 \mathrm{BU}$ is calculated on the basis of farinograph data: water absorption and the degree of softening according to the Serbian official methods (1988). After mixing for 5 minutes, dough was fermented for $120 \mathrm{~min}$ at $30{ }^{\circ} \mathrm{C}$ and $75 \%$ re- lative humidity $(\mathrm{RH})$, with punches after 60 and $90 \mathrm{~min}$. The fermented dough was divided into $130-\mathrm{g}$ portions and proofed for another $70 \mathrm{~min}$ at $30{ }^{\circ} \mathrm{C}$ and $75 \% \mathrm{RH}$ for final proofing. Doughs were baked for 15 min at $220{ }^{\circ} \mathrm{C}$. After cooling at room temperature for $1 \mathrm{~h}$, the loaves were kept in a climate chamber for $23 \mathrm{~h}$ in controlled conditions of temperature $\left(22 \pm 0.7^{\circ} \mathrm{C}\right)$ and humidity $(75 \pm 0.5 \%)$.

\section{CHARACTERIZATION OF BREAD}

\section{Specific volume}

The breads were weighed after cooling for $1 \mathrm{~h}$ and their volume $\left(\mathrm{cm}^{3}\right)$ was determined by millet displacement method. The specific volume $\left(\mathrm{cm}^{3} / \mathrm{g}\right)$ was calculated as loaf volume/bread weight.

\section{Texture measurements}

Bread crumb firmness was measured following the AACC (74-09) standard method on a TA-XTplus Texture Analyser (StableMicro System, Godalming, Surrey, UK) using a 36-mm diameter probe, 30-kg load cell on $12.5-\mathrm{mm}$ thick slices. For each firmness measurement, three samples were used. The analysis of texture was carried out $24 \mathrm{~h}$ after baking.

\section{Statistical analysis}

The experimental data collected was analyzed using the analysis of variance (ANOVA). The comparison among means was done by the Fisher's LSD test regarded significant at $p<0.05$. Statistical method was performed using the Statistica 12.0 software (Statsoft, Tulsa, OK).

\section{RESULTS AND DISCUSSION}

In order to evaluate the frequency of certain quality levels of the analyzed wheat flour samples, shares of selected quality range were graphically presented as well as their average values for each year individually for the following parameters: SD- Degree of softening obtained by Farinograph (BU); E- Energy obtained by Extensograph $\left(\mathrm{cm}^{2}\right)$, PV- Peak viscosity obtained by Amylograph (BU) and W- Deformation energy obtained by Alveograph $\left(\times 10^{-4} \mathrm{~J}\right)$ (Figure 1). These parameters are commonly used to estimate the wheat flour quality for a particular purpose. 

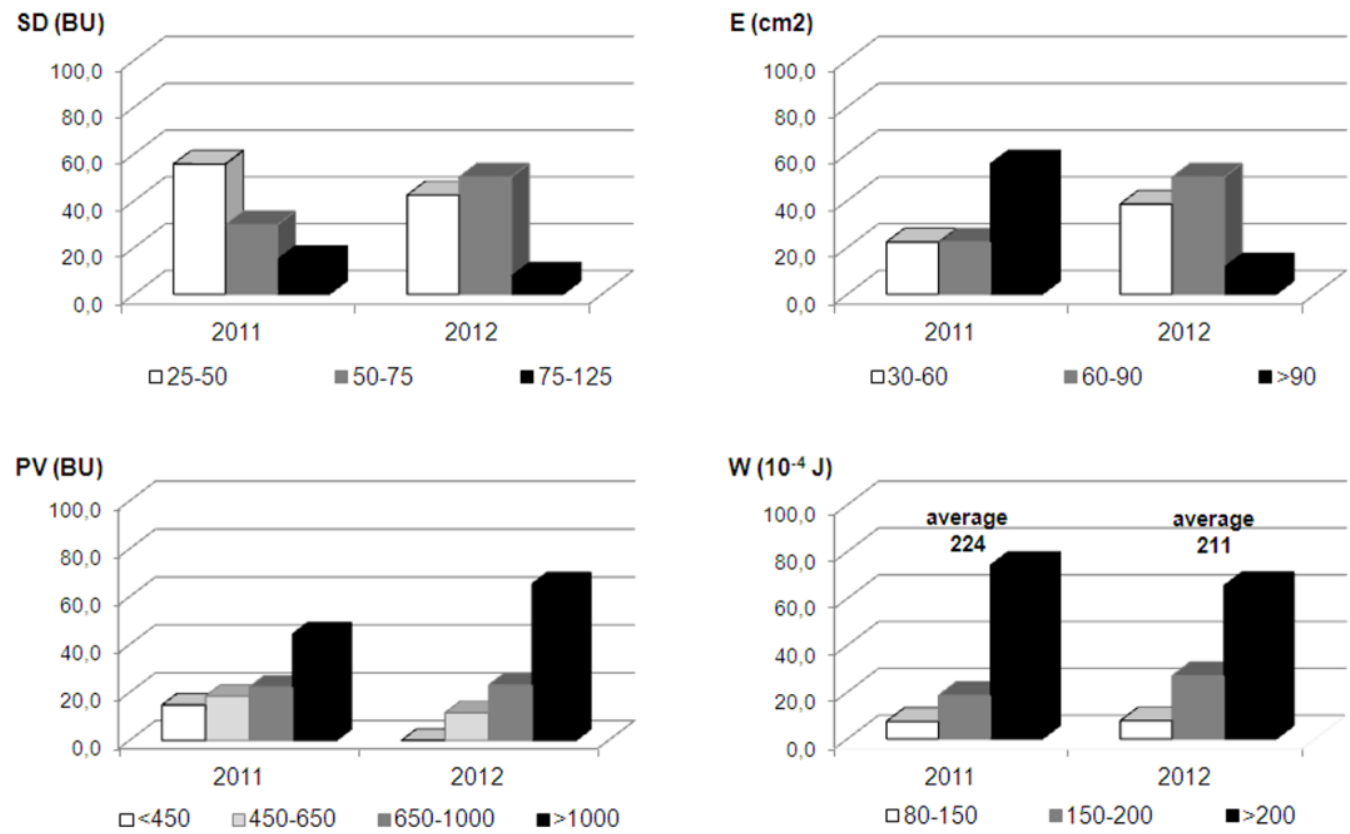

Figure 1. The frequencies of certain quality levels of the tested wheat flour samples from two production years

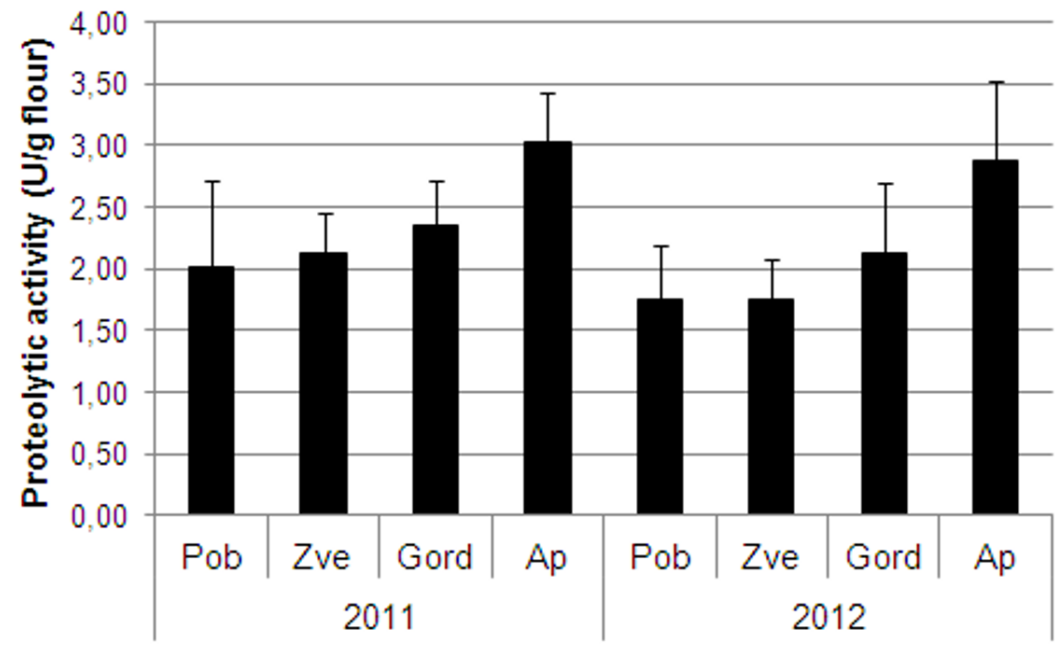

Figure 2. The proteolytic activity in dependence of variety and production year. Error bars represent SD values of each variety on different growing locations

Compared to the 2011 production year, wheat flour samples from 2012 were characterized by inferior quality parameters obtained by Farinograph and Extensograph. In the 2011 production year, there was a higher proportion of samples with lower degree of softening (SD) and higher values of energy (E).

Regarding the alveograph parameter (W), differences between flour samples from the two production years were much smaller, but generally the average value of this parameter indicate a good technological quality (more than $50 \%$ of flour samples had values of $W$ above 200) (AbuHammad et al., 2012).

All tested wheat flour samples exhibited markedly high level of amylograph peak viscosity (PV) regardless of the production year, which were above the optimum 
suitable for processing in baking industry (>650). Within the tested production years, samples from 2012 production year were characterized by significantly higher PV values, i.e. $75 \%$ of flour samples had PV value above 1000 BU. Since the 2012 production year was characterized by higher temperatures during the growing season (from anthesis to harvest) and higher number of days with temperature above $30{ }^{\circ} \mathrm{C}$, it can be assumed that these unfavourable conditions caused the changes in the synthesis of enzymes, primarily amylases (Johansson et al., 2013). On the other hand, a different degree of shorte- ning of the biosynthesis duration of proteins and starch might have happened as well. Changed properties of the starchamylose complex of wheat samples are reflected through differences in the size of starch granules and their morphology, as well as ways of their formation in the endosperm, which could have an influence on peak viscosity values (Thitisaksakul et al., 2012). Based on these findings it can be assumed that high PV values could be the consequence of the way of packing starch granules and their size, not exclusively the consequence of amylolytic activity.

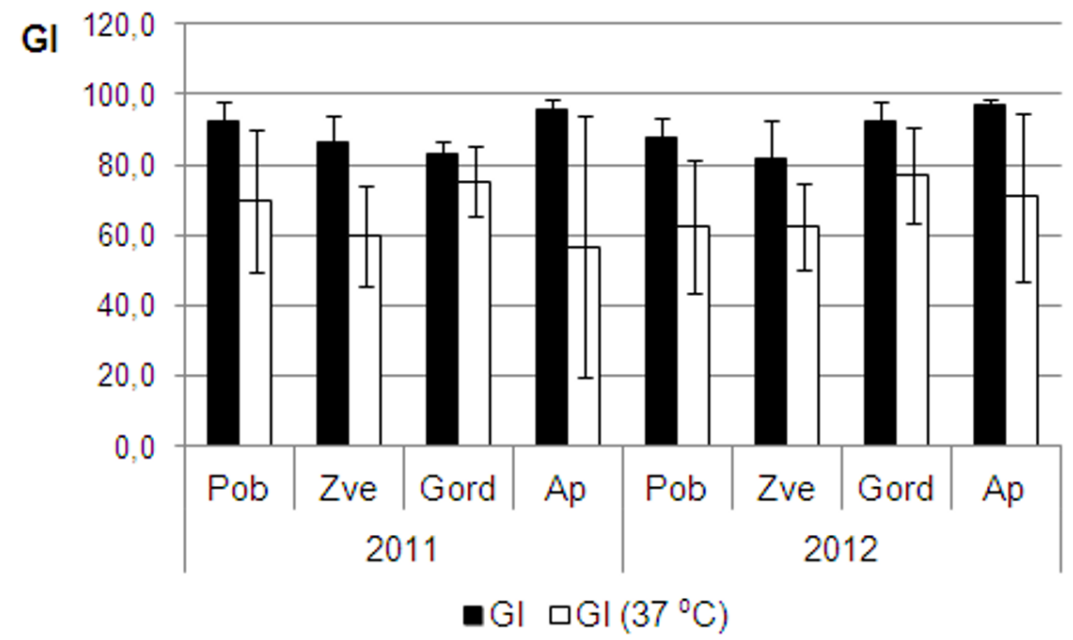

Figure 3. Gluten index values in dependence of variety and production year. Error bars represent SD values of each variety on different growing locations

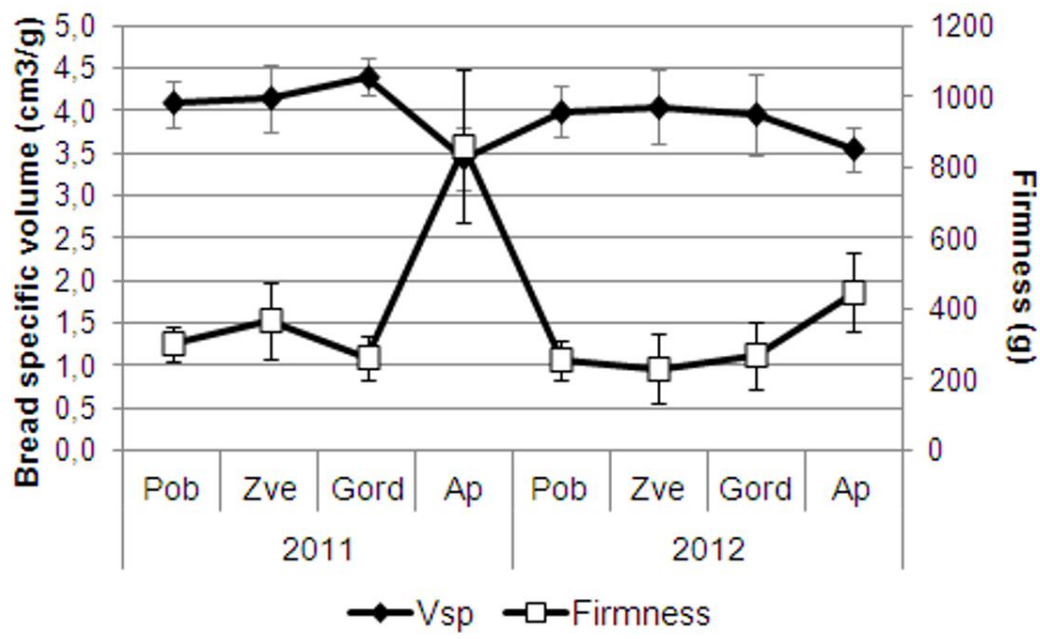

Figure 4. The bread specific volume and crumb firmness in dependence of variety and production year. Error bars represent SD values of each variety on different growing locations 
There are some studies which indicate that wheat flour showed a relatively good breadmaking potential despite a comparatively low $\mathrm{PV}$ values (Ichinose et al. 2001). However, other quality parameters in our study showed relatively good processing quality of the wheat flour samples indicating that redefinition of the importance of common technological parameters is necessary. As a consequence of altered climatic conditions, the same values of standard quality parameters of wheat and wheat flour have a different meaning today than few decades ago.

Figure 2 shows the proteolytic activity of all tested wheat flour samples in two production years. The obtained results showed that variety, growing location as well as production year had strong influence on the proteolytic activity. High values of standard deviation indicated the influence of different growing locations. The proteolytic activity was in the range between 1.05-3.77 U/g. It could be noticed that this parameter was primarily varietal feature but it could not be ignored the impact of climate that prevailed during the tested two years. The total proteolytic activity was significantly higher for the 2011 compared to the 2012 production year. Regarding the varieties, the variety Apache was clearly separated by higher values of this parameter regardless of production year.

Figure 3 shows the results of gluten index (Gl) obtained for all tested wheat flour samples performed without previous incubation and after incubation of dough ball at $37^{\circ} \mathrm{C}$. The values of $\mathrm{Gl}$ as an indicator of gluten strength showed strong influence of variety. Gl obtained without previous incubation of dough ball provides information about the rate of high/low molecular weight proteins i.e. provides information about the strength of gluten (Collar et al., 2007), while the GI values obtained with previous incubation at $37{ }^{\circ} \mathrm{C}$ indicate the degree of gluten hydrolysis as a consequence of increased proteolytic activity. The average values of gluten index (8395.7) for all examined varieties indicated different gluten strength (from strong to very strong) and they were considered to be suitable for obtaining optimum quality bread (Har Gil et al., 2011). Considering the values of standard deviation it could be noticed that the Gl parameter obtained with the standard procedure was not influenced by growing locations. That was not the case for $\mathrm{Gl}$ values after incubation at $37^{\circ} \mathrm{C}$. High standard deviation values, especially for Apache variety indicated relatively weak resistance of varieties to the prevailing microclimate conditions, which contributed to the variation of the tested parameter. These values ( $\mathrm{Gl} 37^{\circ} \mathrm{C}$ ) were lower than those obtained by standard $\mathrm{Gl}$ procedure. Apache variety from 2011 production year showed the greatest decrease of $\mathrm{Gl}$ values after incubation at $37{ }^{\circ} \mathrm{C}$ which was in accordance with results of proteolytic activity.

The results of bread specific volume as one of the important characteristics determining consumer acceptability (Stojčeska and Butler, 2012), showed that samples from 2012 had significantly lower values of this parameter compared to the 2011 production year (Figure 4). Variety Apache differed from other varieties having the lowest specific volume. Also, variety Apache had considerably higher values of firmness, regardless of the production year. Results of bread specific volume were consistent with the results of textural properties of bread because the bread firmness is largely influenced by its volume and crumb porosity (Liu and Scanlon, 2003; Goesaert et al. 2008). According to high PV values of samples from the 2012 production year as indication of amylolytic activity, it could be presumed that the level of amylolytic activity was under optimum which negatively affected the bread specific volume. The same presumption could be made by comparing the results of proteolytic activity and bread specific volume. The higher level of proteolytic activity could act as an effective gluten softener. This effect results in improvement of protein network flexibility, without extensive degradation of glutenins and finally the increase of bread volume (Bombara et al., 1997). 


\section{CONCLUSIONS}

The results of this study have documented large variation for all of the observed wheat quality parameters. This variability was influenced by variety, location and production year. Regarding the parameters of empirical rheological methods, wheat flour samples from the 2012 production year were characterized by inferior quality parameters. Despite the markedly high level of PV values, other quality parameters indicated relatively good processing quality of all tested wheat flour samples. Proteolytic activity and bread specific volume values for the 2012 production year were significantly lower compared to those from 2011. By comparing the results of rheological methods, proteolytic activity and bread specific volume it could be concluded that the level of proteolytic activity was low to cause any quality deterioration. In fact, the obtained results implied that the level of proteolytic activity was under optimum and an increase in proteolytic activity could be beneficial for bread final quality.

\section{ACKNOWLEDGEMENTS}

This paper is a result of the research within the project TR31007 financed by the Ministry of Education, Science and Technological Development of the Republic of Serbia.

\section{REFERENCES}

1. AACC (1999). American Association of Cereal Chemists. Approved Methods. Standard no. 2610.02. (Experimental Milling: Introduction, Equipment, Sample Preparation, and Tempering), Standard no. 26-31.01. (Experimental Milling-Bühler Method for Soft Wheat Straight-Grade Flour).

2. AbuHammad, W.A., Elias, E.M., Manthey, F.A., Alamri, M.S., Mergoum, M. (2012). A comparison of methods for assessing dough and gluten strength of durum wheat and their relationship to pasta cooking quality. International Journal of Food Science and Technology, 47, 2561-2573.

3. Altenbach, S.B. (2012). New insights into the effects of high temperature, drought and postanthesis fertilizer on wheat grain development. Journal of Cereal Science, 56, 39-50.

4. Bombara, N., Añón, M.C., Pilosof, A.M.R. (1997). Functional properties of protease modified wheat flours. LWT-Food Science and Technology, 30, 441447.

5. Calucci, L., Capocchi, A., Galleschi, L., Ghiringhelli, S., Pinzino, C., Saviozzi, F., Zandomeneghi, M. (2004). Antioxidants, free radicals, storage proteins, and proteolytic activities in wheat (Triticum aestivum) seeds during accelerated aging. Agriculturae Conspectus Scientificus, 52, 4274-4281.

6. Collar, C., Bollaín, C., Rosell, C. M. (2007). Rheological behavior of formulated bread doughs during mixing and heating. Food Science and Technology International, 13, 99-107.

7. Dapčević, T., Hadnađev, M., Pojić, M. (2009). Evaluation of the possibility to replace conventional rheological wheat flour quality control instruments with the new measurement tool - Mixolab. Agriculturae Conspectus Scientificus, 74, 169-174.

8. Denčić, S., Mladenov, N., Kobiljski, B. (2011). Effects of genotype and environment on breadmaking quality in wheat. International. Journal of Plant Production, 5, 71-82.

9. Dojczew, D., Sobczyk, M. (2007). The effect of proteolytic activity on the technological value of wheat flour from preharvest sprouted grain. Acta Scientiarum Polonorum, Technologia Alimentaria, 6, 45-53.

10. Dominguez, F., Cejudo, F.J. (1996). Characterization of the endoproteases appearing during wheat grain development. Plant Physiology, 112, 1211-1217.

11. Finlay, G.J., Bullock, P.R., Sapirstein, H.D., Naeem, H.A., Hussain, A., Angadi, S.V., DePauw, R.M., (2007). Genotypic and environmental variation in grain, flour, dough and breadmaking characteristics of western Canadian spring wheat. Canadian Journal of Plant Science, 87, 679-690.

12. Gélinas, P., McKinnon, C. (2011). A finer screening of wheat cultivars based on comparison of the baking potential of wholegrain flour and white flour. International Journal of Food Science and Technology, 46, 1137-1148.

13. Goesaert, H., Leman, P., Delcour, J.A. (2008). Model approach to starch functionality in bread making. Journal of Agricultural and Food Chemistry, 56, 6423-6431.

14. Har Gil, D., Bonfil, D.J., Svoray, T. (2011). Multi scale analysis of the factors influencing wheat quality as determined by Gluten Index. Field Crops Research, 123, 1-9.

15. ICC International Association for Cereal Science and Technology. Standard Methods 114/1, 115/1, 121, 126/1 (1992), 155 (1994).

16. Ichinose, Y., Takata, K., Kuwabara, T., Iriki, N., Abiko, T., Yamauchi, H. (2001). Effects of increase in -amylase and endoprotease activities during germination on the breadmaking quality of wheat. Food Science and Technology Research, 7 (3), 214-219.

17. Johansson, E., Malik, A.H., Hussain, A., Rasheed, F., Newson, W.R., Plivelic, T., Hedenqvist, M.S., Gällstedt, M., Kuktaite, R. (2013). Wheat gluten polymer structures: The impact of genotype, environment, and processing on their functionality in various applications. Cereal Chemistry, 90, 367-376.

18. Kruger, J.E., Preston, K. (1977). The distribution of carboxypeptidases in anatomical tissues of developping and germinating wheat kernels. Cereal Chemistry, 54, 167-174.

19. Liu Z., Scanlon, M.G. (2003). Predicting mechnical properties of bread crumb. Food and Bioproducts Processing, 81, 224-238.

20. Lowry, O.H., Rosenbrough, N.J., Fair, A.L., Randall, R.J. (1951). Protein measurement with the Folinphenol reagents. Journal of Biological Chemistry, 193, 265-275.

21. Pravilnik (1988). Pravilnik o metodama fizičkih i hemijskih analiza za kontrolu kvaliteta žita, mlinskih i pekarskih proizvoda, testenina i brzo smrznutih testa. Službeni list SFRJ, 74 (Regulation on methods of physical and chemical analysis for quality control of cereal grains, milling and bakery products, pasta and quick frozen dough). 
22. Preston, K.R., Hucl, P., TownleySmith, T.F., Dexter, J.E., Williams. P.C., Stevenson, S.G. (2001). Effects of cultivar and environment on farinograph and Canadian short process mixing properties of Canada Western Red Spring wheat. Canadian Journal of Plant Science, 81, 391-398.

23. Rani, K.U., Prasada Rao, U.J.S., Leelavathi, K., Haridas Rao, P. (2001). Distribution of enzymes in wheat flour mill streams. Journal of Cereal Science, 34, 233-242.

24. Souza, E.J., Martin, J.M., Guttieri, M.J., O'Brien, K.M., Habernicht, D.K., Lanning, S.P., McLean, R., Carlson, G.R., Talbert, L.E. (2004). Influence of genotype, environment and nitrogen management on spring wheat quality. Crop Science, 44, 425-432.

25. Stojceska, V., Butler, F. (2012). Investigation of reported correlation coefficients between rheological properties of the wheat bread doughs and baking performance of the corresponding wheat flours. Trends in Food Science \& Technology, 24, 13-18.

26. Strelec, I., Ugarčić-Hardi, Ž., Balkić, J., Šimunić, N. (2007). Enzymatic activity in wheat seeds of different protein content. Agriculturae Conspectus Scientificus, 72, 239-243.
27. Thitisaksakul, M., Jiménez, R.C, Arias, M.C., Beckles, D.M. (2012). Effects of environmental factors on cereal starch biosynthesis and composition. Journal of Cereal Science, 56, 67-80.

28. Torbica, A., Antov, M., Mastilović, J., Knežević, D. (2007). The influence of changes in gluten complex structure on technological quality of wheat (Triticum aestivum L.). Food Research International, 40, 10381045.

29. Vázquez, D., Berger, A.G., Cuniberti, M., Bainotti, C., Zavariz de Miranda, M., Scheeren, P.L., Jobet, C., Zúñiga, J., Cabrera, G., Verges, R., Peña R.J. (2012). Influence of cultivar and environment on quality of Latin American wheats. Journal of Cereal Science, 56, 196-203.

30. Wrigley, C.W. (2007). Mitigating the damaging effects of growth and storage conditions on grain quality. In Wheat production in stress environments. Developments in plant breeding. Eds. H.T. Buck, J.E. Nisi, N. Salomón, Dordrecht, The Netherlands, pp. 425-439.

31. Zhang, Y., He, Z.H., Ye, G.Y., Zhang, A.M., Maarten, V.G. (2004). Effect of environment and genotype on breadmaking quality of springsown spring wheat cultivars in China. Euphytica, 139, 75-83.

\title{
ПЕЦИВНИ КВАЛИТЕТ И ПРОТЕОЛИТИЧКА АКТИВНОСТ БРАШНА СОРТИ ПШЕНИЦЕ ПОРЕКЛОМ ИЗ ДВЕ ПРОИЗВОДНЕ ГОДИНЕ СА РАЗЛИЧИТИМ КЛИМАТСКИМ УСЛОВИМА
}

\author{
Јелена М. Томић ${ }^{1 *}$, Александра М. Торбица ${ }^{1}$, Љиљана М. Поповић ${ }^{2}$, Слађана М. Ракита ${ }^{1}$, \\ Драган Р. Живанчев ${ }^{1}$
}

\footnotetext{
${ }^{1}$ Универзитет у Новом Саду, Научни институт за прехрамбене технологије у Новом Саду, Булевар цара Лазара 1, 21000 Нови Сад, Србија

${ }^{2}$ Универзитет у Новом Саду, Технолошки факултет, Булевар цара Лазара 1 ,
} 21000 Нови Сад Србија

Сажетак: Пшенично брашно представља комплексан систем чији је квалитет условљен бројним фракторима као што су генотип, услови гајења и комплексне интеракције генетских и еколошких фактора. У последњих неколико година, фрлуктуација квалитета пшенице представља велики проблем за млинаре и пекаре. Захтеви пекарске индустрије за обезбеђењем пшеничног брашна уједначеног квалитета намећу потребу за даљим истраживањима у правцу мониторинга/побољшања квалитета пшенице и пшеничног брашна. Стога, циљ овог рада био је процена пецивног потенцијала и нивоа протеолитичке активности брашна четири сорте пшенице (Победа, Звездана, Гордана и Апач) пореклом са седам локалитета различитих микроклиматских услова током две производне године. Поред одређивања протеолитичке активности, испитана су реолошка својства теста применом уобичајених метода за процену технолошког квалитета брашна. Урађена је метода пробног печења и испитана су текстурна својства готовог производа-хлеба. За све мерене показатеље квалитета, уочљива је широка варијабилност, која је највише под утицајем сорти. Узорци пшеничног брашна из 2012. производне године су се одликовали нижим вредностима показатеља технолошког квалитета. Вредности протеолитичке активности и специфичне запремине хлеба су биле значајно ниже за поменуте узорке у односу на узорке из 2011. производне године. Ови резултати показују да је ниво протеолитичке активности био испод оптималног за добијање хлеба веће специфичне запремине.

Кључне речи: пшенично брашно, пецивни квалитет, протеолитичка активност

Received: 6 October 2015 